\title{
Review: Studies and Applications of Stable Isotopes in Precipitation
}

\author{
Kimpei ICHIYANAGI ${ }^{* 1}$
}

\begin{abstract}
This paper reviews observation- and model-based studies of stable isotopes in precipitation and discusses the Global Network for Isotopes in Precipitation (GNIP) and other regional networks and projects involving isotope observations. Using data from the latest GNIP/Isotope Hydrology Information System (ISOHIS) database, the annual and monthly variabilities of $\delta \mathrm{D}-\delta{ }^{18} \mathrm{O}$ relationships, the temperature effect, and the amount effect for $\delta^{18} \mathrm{O}$ were calculated as averages for the Northern Hemisphere, Southern Hemisphere, and globe. At the global scale, the global Meteoric Water Line (MWL) was $\delta \mathrm{D}=8.00 \times \delta^{18} \mathrm{O}+9.62\left(\mathrm{R}^{2}=0.99\right)$, the temperature effect was $0.53 \%{ }^{\circ}{ }^{\circ} \mathrm{C}\left(\mathrm{R}^{2}=0.71\right)$, and the precipitation amount effect was $-1.05 \% \circ / 100 \mathrm{~mm}\left(\mathrm{R}^{2}=0.20\right)$. Comparisons of modeled and observed temperature and amount effects indicate that most General Circulation Models (GCMs) have reproduced the present climate well. This paper also summarizes the use of stable isotopes in precipitation as proxy data for climate variability and water origins, as well as the results of recent isotope-observation studies, especially in the Asian monsoon regions.
\end{abstract}

Key words: climate variability, GCMs, paleoclimate, stable isotopes in precipitation

\section{Introduction}

Stable isotopes in precipitation $\left(\delta \mathrm{D}, \delta^{18} \mathrm{O}\right)$ contain information on both the origins of precipitation and its transport because heavy and light isotope species undergo different fractionation during phase changes. Since the 1960 s and the development of mass spectrometry, climate-change studies have used measurements of the stable isotopes in precipitation as proxy data for the temperature and amount of precipitation to reproduce the paleoclimate. Many natural paleoclimatic archives (e.g., ice cores, lake sediments, corals, tree rings, limestone caves, and groundwater) preserve the isotopic composition of precipitation, which can be used to estimate past climate variations. One of the most important applications of stable isotopes in precipitation is the reconstruction of past climates based on the direct relationship between temperature and isotopes in ice cores. Whereas the link between the isotope signature of precipitation and climate in the polar regions is relatively well understood, less is known of this link in temperate and tropical areas (Rozanski $e t$ $a l ., 1992)$. The spatial and temporal distributions of stable isotopes in precipitation in modern meteoric waters have also revealed a close relationship between isotopic variability and some

\footnotetext{
* 1 Institute of Observational Research for Global Change (IORGC), Japan Agency for Marine-Earth Sciences and Technology (JAMSTEC)
} 
meteorological parameters. However, as Vuille et al. (2003a) noted, the ${ }^{18} \mathrm{O}$ signal in precipitation is influenced by a combination of factors, such as precipitation amount, temperature, moisture source variability, and atmospheric circulation changes. Recent modeling efforts have confirmed that the interpretation of isotopic data using only local meteorological conditions, such as temperature, can lead to incorrect reconstructions of the paleoclimate (Noone and Simmonds, 2002a).

Here, I review the studies and applications of stable isotopes in precipitation. Section II focuses on observational networks for precipitation isotopes, while Section III discusses observed isotopic effects on current precipitation. General Circulation Models (GCMs) and land surface models that incorporate isotopic processes are examined in Section IV. Section V discusses the use of isotopic data as a proxy for climate change, with a focus on the Asian monsoon regions.

\section{Observational Networks}

\section{GNIP Network}

Most studies of stable isotopes in precipitation on a global scale have relied on data from the Global Network for Isotopes in Precipitation (GNIP), begun in 1961 by the International Atomic Energy Agency (IAEA) in cooperation with the World Meteorological Organization (WMO). Dansgaard (1964) described the aims of the GNIP project as (1) providing knowledge of tritium input functions in various parts of the world, a parameter necessary for the application of natural tritium to hydrological problems, and (2) obtaining data on the concentrations of hydrogen and oxygen isotopes, for use in deducing certain characteristics of the circulation patterns and mechanisms of global and local water movement.
The network began with more than 100 meteorological stations in 65 countries and territories, collecting monthly composite precipitation samples for isotope analysis. The number of stations had grown to 220 by 1963-64, but it subsequently decreased with the decline of tritium in the atmosphere due to nuclear weapons testing. Technical reports published regularly by the IAEA have provided isotope and meteorological data (IAEA, 1969, 1970, 1971, 1973, 1975, 1979, 1983, 1986, 1990). Recently, the data from the network have been used as benchmarks for the interpretation of paleorecords, as a validation tool for GCMs, and to establish regional- and continental-scale water balances (IAEA/WMO, 2004). The "Isotopes in the Hydrological Cycle" (ISOHYC) initiative was established to focus on the use of hydrogen and oxygen isotopes both to improve our understanding of present trends in climate variability and to help reconstruct past variations in climate based on the isotopes present in natural archives (Oeschger, 2000). The GNIP data have been summarized (Rozanski et al., 1993; IAEA, 2001) and are now available from the Isotope Hydrology Information System (ISOHIS) developed by the Isotope Hydrology Section of the IAEA (accessible at http://isohis.iaea.org/ISOHIS.asp). However, the data from several stations in the GNIP database suffer from coarse spatial resolution and short temporal resolution, which limits their use in circulation studies. Further, the monthly resolution of the GNIP data can mask the influence of individual storms on the isotope record (Burnett et al., 2004).

\section{Other Networks}

A number of national networks have been established that contribute to the GNIP (accessible at http://isohis.iaea.org/userupdate/nationalnetworks. html). For example, the Canadian Network for 
Isotopes in Precipitation has 33 precipitation stations (accessible at http://www.science.uwaterloo. ca/ twdedwar/cnip/cniphome.html), the Swiss National Network for the Observation of Isotopes in the Water Cycles has eleven precipitation stations, seven river stations, and three groundwater stations (accessible at http://www.bafu.admin.ch/ hydrologie/01831/01846/index.html), the United States Network for Isotopes in Precipitation has 81 precipitation stations (accessible at http://www.nrel. colostate.edu/projects/usnip/), and France's Banque de Deonnées Isotopiques has 82 precipitation stations, 162 river stations, and 1,229 groundwater stations (accessible at http://infoterre.brgm.fr). One of the oldest and densest networks in the world, the Austrian Network of Isotopes in Precipitation (ANIP), started in 1972. Liebminger et al. (2006) investigated the processes governing the isotopic composition of precipitation in alpine regions using data collected from 12 ANIP stations in Austria from 1972 to 2003.

In Asia, the Global Energy and Water Cycle Experiment (GEWEX) and GEWEX Asian Monsoon Experiment (GAME) were implemented to understand the role of the Asian monsoon in global energy and water cycles and to improve the simulation and seasonal prediction of Asian monsoon patterns and regional water resources (accessible at http://www.hyarc.nagoya-u.ac.jp/game/). Under the GAME project, isotopic observations were conducted in Siberia, the Tibetan Plateau, and Thailand. Some of the isotopic observations started by the GAME project in Siberia, the Tibetan Plateau, and Thailand were continued by the Institute of Observational Research for Global Change (IORGC) of the Japan Agency for MarineEarth Science and Technology (JAMSTEC). The IORGC has also monitored stable isotopes in precipitation, river water, and water vapor in Indonesia, Thailand, Vietnam, the Palau Republic, the Maldives, Siberia, Mongolia, the Tibetan Plateau, and Nepal. Precipitation reaching the ocean has also been sampled during each cruise of the research vessel Mirai. Some of these isotopic data are available from the database of Hydrological Cycle Observational Research Program of the IORGC (accessible at http://www.jamstec. go.jp/iorgc/ hcorp/data/database).

The Siberian Network of Isotopes in Precipitation (SNIP) observation program gathered monthly precipitation samples at 13 meteorological stations across Russia from January 1996 to December 2000. Kurita et al. (2004) described the spatial and temporal variations in the stable isotopic composition of precipitation based on SNIP observations. In Siberia, more than half of the moisture originated from land surfaces, and the isotopic content of the precipitation was controlled mainly by the contribution of recycled water. Daily and weekly precipitation samples were also collected around Yakutsk by a joint project of GAME and the IORGC in 2000. As reported by Kurita et al. (2003), summer precipitation was a composite of source water from the west with a heavy isotopic ratio and recycled water from the land surface. Additionally, deposited snow samples were obtained in two snow surveys of Siberia in 2000 and 2001; the results indicated inland $\delta \mathrm{D}$ depletion and a slightly increasing deuterium-excess (Kurita et al., 2005). The contribution of land-derived moisture that has evaporated from open water plays an important role in eastern Siberian snow. As reported by Sugimoto et al. (2003), soil and plant water samples collected around Yakutsk from 1997 and 2000 further suggest that during severe summer droughts, plants utilize permafrost meltwater. Ichiyanagi et al. (2003) reported on detailed measurements of temporal variations in stable isotopes of precipitation and lake water collected in the permafrost region around Yakutsk in 2000. 
They noted that the temporal volumetric and isotopic variations in a small lake were reproduced well by an isotope mass-balance model including Rayleigh fractionation. The lake water originated from snowmelt (lake water evaporated in the previous summer) in an isotopic steady- (nonsteady-) state with less than 5\% (more than 10\%o) seasonal variation.

Precipitation and subsurface water samples were also collected on the Tibetan Plateau during the monsoon season in 1998 , and $\delta^{18} \mathrm{O}$ enrichment in the groundwater due to precipitation was associated with evaporation from the soil surface (Tsujimura et al., 2001). As reported by Tian et al. (2001a, b), data collected during individual precipitation events and from river water showed the spatial distributions of $\delta^{18} \mathrm{O}$ and deuteriumexcess of precipitation, which revealed three moisture sources: (1) moisture provided by the Indian monsoon and recycled over the Indian Peninsula, (2) oceanic moisture directly transported from the Bay of Bengal, and (3) recycled continental water. Additionally, precipitation samples from the Tibetan Plateau collected at four stations from 1992 to 2000 (Tian et al., 2003) and at seven stations from 1998 to 2002 (Tian et al., 2007) revealed the impact of monsoon precipitation on the spatial distribution of the $\delta^{18} \mathrm{O}$-temperature relationship. Strong monsoon activity in the southern Tibetan Plateau resulted in high precipitation rates and greater depletion of heavy isotopes (i.e., the amount effect). Meanwhile, Yoshimura et al. (2003) compared daily precipitation isotope data observed during the GAME-Thailand (GAME-T) project in 1998 and 1999 to simulation results by a Rayleigh-type isotope circulation model. Since 2001, precipitation isotopes have been monitored daily by the IORGC project at seven stations in Thailand. Ichiyanagi et al. (2005) used the data from 2001 to estimate water origins and to develop a new definition of the withdrawal date of the Asian summer monsoon over Indochina. In India, the Isotopes in Waters of India Network (IWIN) was designed to monitor spatial and temporal variations in the isotopic composition of atmospheric water vapor, rain, major surface water sources, and groundwater to provide a more detailed understanding of the natural hydrological cycle (Gupta and Deshpande, 2005).

\section{Effects on Isotopes in Precipitation}

\section{Global Distribution of Observations}

Craig (1961) showed the global relationship betweend $\mathrm{D}$ and $\delta^{18} \mathrm{O}$ in 400 samples of water from rivers, lakes, and precipitation, obtaining a straight-line relationship of $\delta \mathrm{D}=8 \times \delta^{18} \mathrm{O}+10$, called the global Meteoric Water Line (MWL). Dansgaard (1964) considered the temperature effect, amount effect, and $\delta$ and $\delta{ }^{18} \mathrm{O}$ relationship, reporting $\delta D^{-} \delta^{18} \mathrm{O}$ slopes of 8.0 and 4.6 for continental and tropical island stations in the Northern Hemisphere, respectively.

The GNIP/ISOHIS Database (IAEA/WMO, 2004) also provides the arithmetic and weighted monthly means of $\delta \mathrm{D}, \delta^{18} \mathrm{O}$, deuterium-excess, precipitation amount, surface air temperature, and water vapor pressure calculated for the period 1961 to 2001 for stations having at least 3 years of information. The weighted monthly means of $\delta{ }^{18} \mathrm{O}$ at 314 stations were averaged on a grid with a horizontal resolution of $2.5^{\circ}$ in both longitude and latitude to examine the spatial distribution at the global scale. Figure $\mathbf{1}$ presents the spatial distribution of annual mean $\delta^{18} \mathrm{O}$ in precipitation. While there were numerous stations in Europe, China, and South America, there were not enough stations worldwide to show the global distribution of isotopes in precipitation. The annual mean $\delta^{18} \mathrm{O}$ ranged from more than $0 \%$ in the tropics to less 


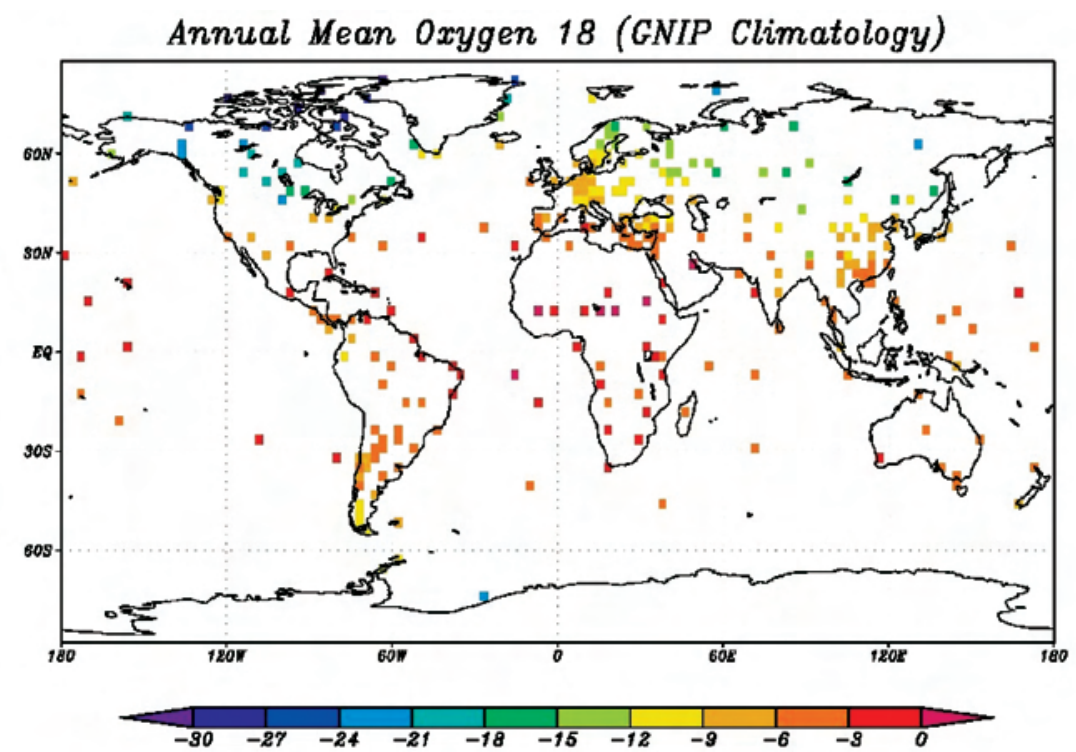

Figure 1 Distribution of annual mean $\delta^{18} \mathrm{O}$ in precipitation based on the GNIP/ISOHIS database.

than $-30 \%$ in the polar regions and was relatively higher in the coastal regions than in the continental regions of Eurasia and North America. The figure clearly shows these latitudinal and continental effects. These spatial distributions were related to environmental parameters such as latitude, altitude, distance to the coast, amount of precipitation, and surface air temperature at the sampling site (Dansgaard, 1964). Figure 2 illustrates the relationship between $\delta \mathrm{D}$ and $\delta^{18} \mathrm{O}$ in precipitation. The annual mean $\delta^{18} \mathrm{O}$ in the Northern Hemisphere ranged from $-40 \%$ to $10 \%$, while the values in the Southern Hemisphere ranged from $-30 \%$ to $3 \%$. At some high-latitude stations in North America and Greenland, the $\delta^{18} \mathrm{O}$ values fell below $-30 \%$; however, most stations in Africa recorded values of more than $-3 \%$. For the Northern and Southern hemispheres, the obtained regression lines were $\delta \mathrm{D}=7.96 \times \delta^{18} \mathrm{O}+9.11$ and $\delta \mathrm{D}=8.23 \times \delta^{18} \mathrm{O}+11.29$, respectively. The global MWL, based on GNIP/ISOHIS data, was $\delta \mathrm{D}=$ $8.00 \times \delta^{18} \mathrm{O}+9.62$; the slope of this line corresponds to the theoretical result under isotopic equilibrium conditions. However, there were spatial and temporal variabilities in the slope and intercept of the $\delta \mathrm{D}-\delta^{18} \mathrm{O}$ linear relationship for precipitation. Different sources of water vapor with different isotope characteristics, different air mass trajectories, or different evaporation and isotope exchange processes below the cloud base may lead to much more complex relationships between $\delta \mathrm{D}$ and $\delta^{18} \mathrm{O}$ at the local level (Hoefs, 2004).

Figure 3 shows their seasonal variability calculated for the Northern and Southern hemispheres. The slope of the global MWL ranged from 7.8 to 8.5 , while those in the Northern and Southern Hemispheres were approximately 8.0 and more than 8.25 , respectively. The seasonal variation of the slope of the global mean was close to that for the Northern Hemisphere. The slope in boreal summer was relatively higher than that in winter. The intercept of the MWL ranged from 8 to 14 , with the values from April to October in the Northern Hemisphere much lower than those in 

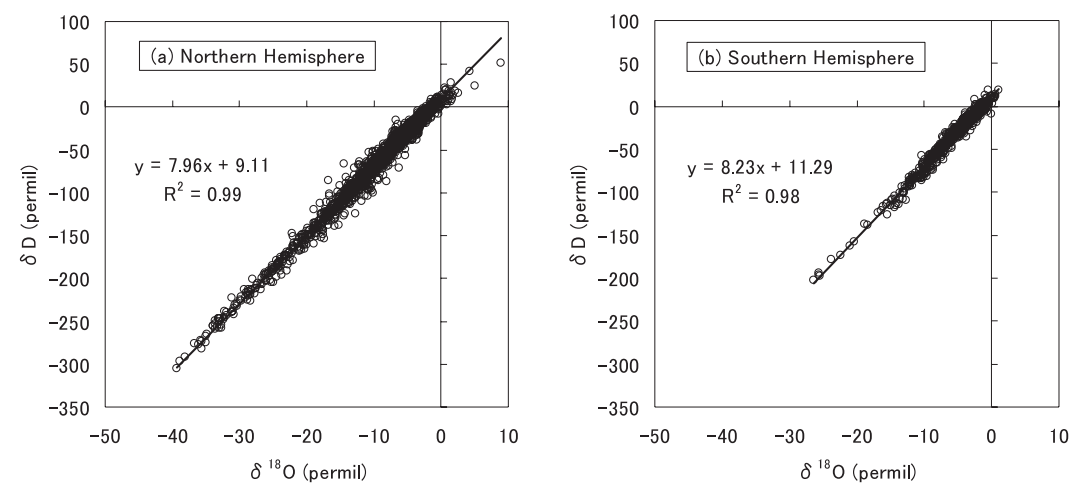

Figure 2 Relationship between monthly $\delta \mathrm{D}$ and $\delta^{18} \mathrm{O}$ in precipitation over the (a) Northern and (b) Southern Hemispheres.
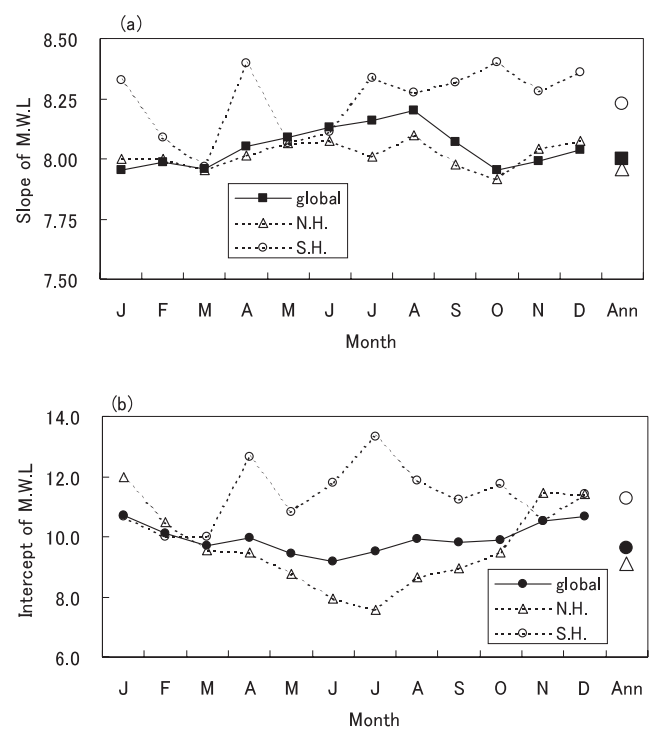

Figure 3 Monthly and annual (a) slope and (b) intercept of $\delta \mathrm{D}-\delta^{18} \mathrm{O}$ in precipitation calculated for the Northern Hemisphere, Southern Hemisphere, and globe.

the Southern Hemisphere. The seasonal variation of the intercept of the global mean MWL was also close to that of the Northern Hemisphere. This result may be explained by the larger number of stations in the Northern Hemisphere than in the Southern Hemisphere. Comparison of $\delta \mathrm{D}-\delta^{18} \mathrm{O}$ relationships for marine and continental stations showed that the slope and deuterium-excess were usually smaller at marine stations (Rozanski et al., 1993). At the marine stations, the correlation between $\delta \mathrm{D}$ and $\delta{ }^{18} \mathrm{O}$ was very poor because most precipitation probably came from nearby sources and represented the first stage of the rain-out process. Differences in the seasonality of $\delta \mathrm{D}-\delta^{18} \mathrm{O}$ relations between the Northern and Southern Hemispheres may have been caused by differences in the numbers of marine and continental stations in the hemispheres.

\section{Temperature Effect}

Dansgaard (1964) showed a strong correlation for the plains stations between the annual mean $\delta^{18} \mathrm{O}$ and temperature on a global scale, with an average change of $0.7 \% \circ /{ }^{\circ} \mathrm{C}$. In addition, Rozanski et al. (1992) showed that the long-term annual temperature effect averaged only in European stations was around 0.60 . The slope of the stable isotopes in precipitation versus temperature is important because it can be used to estimate paleotemperature changes and to validate the accuracy of GCM outputs. On the other hand, Kohn and Welker (2005) examined the relationships between the $\delta^{18} \mathrm{O}$ of modern precipitation and surface temperature, but found that the temperature coefficient $\left(\Delta \delta^{18} \mathrm{O} / \Delta \mathrm{T}\right)$ differed depending on the 
time interval (e.g., mean weekly, monthly, or annual temperature). The temperature during precipitation events systematically differed from the time-averaged surface temperature. Correction for this bias using hourly weather and monthly isotope data from U.S. sites yielded a single value of $\sim 0.55 \%$ o In addition, Fricke and O’Neil (1999) showed that the $\delta^{18} \mathrm{O}$-temperature relationships for summer and winter differed widely in middle and high latitudes, which could lead to serious underestimates of temperature change. Thus, the monthly temperature effect calculated by the GNIP/ISOHIS database (IAEA/WMO, 2004) was compared to the annual temperature effect reported by previous studies. The global temperature effect on monthly temperature below $15^{\circ} \mathrm{C}$ was calculated based on the long-term monthly mean temperature and $\delta{ }^{18} \mathrm{O}$ in precipitation. Because the $\delta^{18} \mathrm{O}$ gradient is influenced by the temperature range, some previous studies (e.g., Koster et al., 1993; Hoffmann and Heimann, 1997) considered only sampling sites at which the annual temperature was below $15^{\circ} \mathrm{C}$. Figure 4 shows the relationship between temperature and $\delta^{18} \mathrm{O}$ in precipitation, with a temperature effect of $0.53 \%$ and $R^{2}=0.71$. Seasonal variation in the temperature effect for all stations is also shown in Figure 5. The temperature effect was $0.3 \%$ - $0.5 \%$ globally, but $0.4 \%$ o $-0.6 \%$ and $0.2 \% 0-0.4 \%$ in the Northern and Southern Hemispheres, respectively. The monthly temperature effect in this study was slightly smaller than previously reported annual effects (Dansgaard, 1964; Rozanski et at., 1993), but almost the same as the monthly temperature effect found at U.S. sites (Kohn and Welker, 2005).

Many observational studies have reported on the temperature effect at individual stations. Rozanski et al. (1992) summarized the temperature effect at individual stations and showed that the long-term annual temperature coefficient values

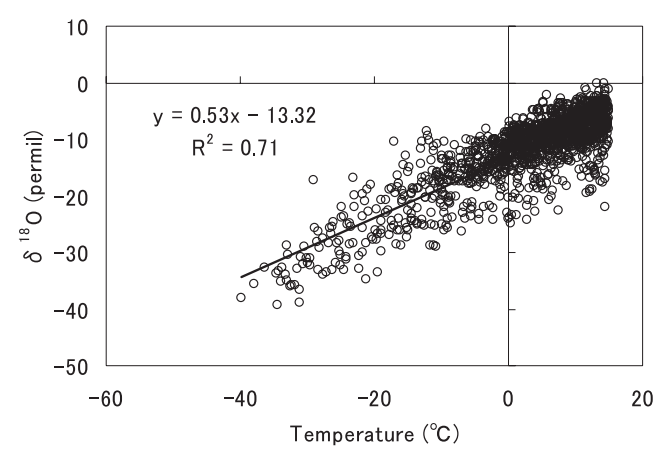

Figure 4 Relationship between monthly temperature and $\delta^{18} \mathrm{O}$ in precipitation at temperatures below $15^{\circ} \mathrm{C}$.

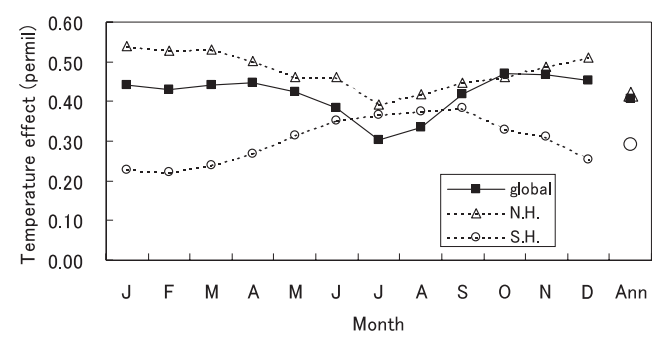

Figure 5 Monthly and annual temperature effects of $\delta^{18} \mathrm{O}$ in precipitation calculated for the Northern Hemisphere, Southern Hemisphere, and globe.

ranged from $0.25 \%$ to $1.10 \%$. Siegenthaler and Oeschger (1980) analyzed the monthly precipitation isotopes in Switzerland; they found a $0.45 \%$ o seasonal variation in the temperature effect, which was valid for long-term temperature changes and therefore for the interpretation of paleo-isotope records in Central Europe. Datta et al. (1991) reported that the temperature effect in New Delhi, India, differed with the monthly rainfall. The $\delta^{18} \mathrm{O}$ gradient was $0.97 \%$ when the monthly rainfall was less than $30 \mathrm{~mm}$ (from April to November), but it was $1.36 \%$ when the monthly rainfall was greater than or equal to $30 \mathrm{~mm}$ (from May to October). To examine the variation in stable isotopes in precipitation at Ürümqi, in China's westernmost province, Zhang et al. (2003) used a mathematical 
model that accounted for the kinetic fractionation effect in a supersaturation environment (at the ice surface as the liquid and solid phases coexist in a mixed cloud) and found that the temperature effect was $0.41 \%$. For Slovenia and Croatia, Vreča et al. (2006) reported a strong correlation between monthly temperature and $\delta^{18} \mathrm{O}$ for the continental stations only, with a temperature effect ranging from $0.15 \%$ o to $-0.37 \%$. These findings demonstrate that the temperature- $\delta{ }^{18} \mathrm{O}$ relationship has large variations that depend on time and location.

The dependence of the temperature effect on the latitude for all stations was calculated based on the long-term monthly mean temperature and $\delta^{18} \mathrm{O}$ in precipitation (IAEA/WMO, 2004). Figure 6 illustrates the relationship between latitude and the temperature effect, showing only those stations with correlation coefficients greater than 0.8. Only the stations in the middle and high latitudes (greater than $30^{\circ}$ in the Northern and Southern Hemispheres) had temperature effects between $0.15 \%$ and $0.50 \%$. While the precipitation amount effect was larger than in the low latitudes, the temperature effect was not obvious. These values were relatively smaller than those in some previous studies (e.g., Rozanski et al., 1992; Datta et al., 1991), possibly because the long-term

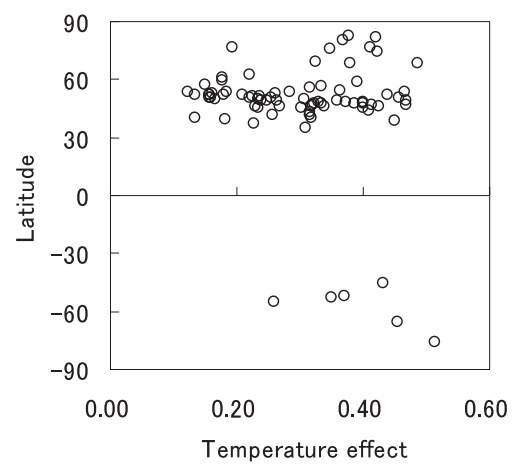

Figure 6. Latitudinal profile of the temperature effect of $\delta^{18} \mathrm{O}$ in precipitation. monthly mean data may have obscured interannual variations both in temperature and $\delta^{18} \mathrm{O}$ in precipitation.

\section{Amount Effect}

The apparent correlation between the amount of monthly precipitation and its isotopic composition was first observed by Dansgaard (1964) and named the "amount effect." The processes controlling the amount effect were summarized as the rain-out process of deep convective clouds, isotope exchange and partial evaporation of raindrops below the cloud base, and changes in the isotopic composition of vapor in the source region (Rozanski et al., 1993). The global amount effect has been calculated using long-term monthly mean precipitation data and $\delta^{18} \mathrm{O}$ values from the GNIP/ISOHIS database (IAEA/WMO, 2004). Figure 7 shows the relationship between the precipitation amount and its $\delta^{18} \mathrm{O}$, with the amount effect of $-1.05 \%$ o $/ 100 \mathrm{~mm}$ and $\mathrm{R}^{2}=0.20$. This amount effect was observed year-round at most tropical stations and in the summer in the mid-latitudes, but never at the polar stations, where the temperature effect was the dominant factor (Dansgaard, 1964). Araguás-Araguás et al. (1998) reported on the spatial and temporal variability of stable isotopes of precipitation in the

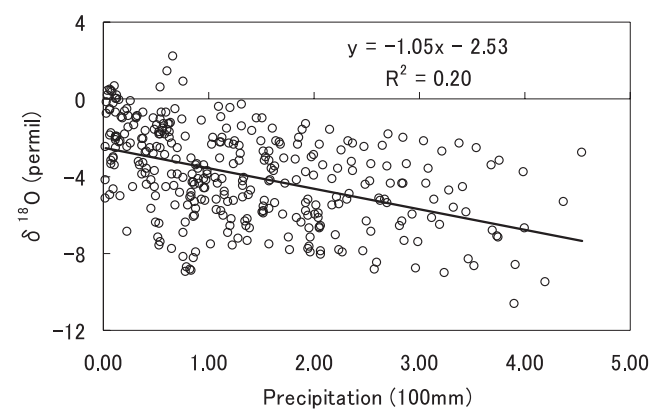

Figure 7 Relationship between the monthly precipitation amount and its $\delta^{18} \mathrm{O}$. 
Southeast Asian and western Pacific regions, noting that the seasonal variability of stable isotopes of precipitation was mainly controlled by temperature and the amount effect in the northern and southern parts of these regions, respectively.

Many observational studies have discussed the amount effect at individual stations, mainly in the low and middle latitudes. Yapp (1982) reproduced the amount effects for tropical oceanic islands in the Pacific using a precipitation intensity model that assumed air-mass cooling due to vertical motion. The $\delta \mathrm{D}$ values associated with precipitation of variable intensity could be predicted in terms of the vertical ascent rate. Lachniet and Patterson (2006) found that the coefficient of the amount effect of $\delta^{18} \mathrm{O}$ over Panama ranged from $-1.63 \%$ to $-2.47 \%$ o $/ 100 \mathrm{~mm}$, and they concluded that the dominant controls on precipitation isotopes associated with the Central American monsoon were temporal and spatial amount effects. Njitchoua et al. (1999) considered the factors controlling variations of stable isotopes in precipitation events in Cameroon, Central Africa. The elevated $\delta^{18} \mathrm{O}$ values (from $+2 \%$ to $-7 \%$ ) in the warm monsoon rains were plotted as a function of the amount of precipitation, the formation of which did not involve lowtemperature condensation. In contrast, the reduced $\delta^{18} \mathrm{O}$ values for relatively light rains could be explained by the condensation of residual vapor in a cloud system, or by condensation at high altitudes. They also noted the importance of moisture recycling at inland stations. The amount effect at individual stations was also calculated based on the long-term monthly mean precipitation and its $\delta^{18} \mathrm{O}$ from the GNIP/ISOHIS database (IAEA/WMO, 2004). Figure 8 shows the dependence of the amount effect on latitude for those stations for which the correlation coefficient exceeded 0.8 . Almost all of these stations were located in the low

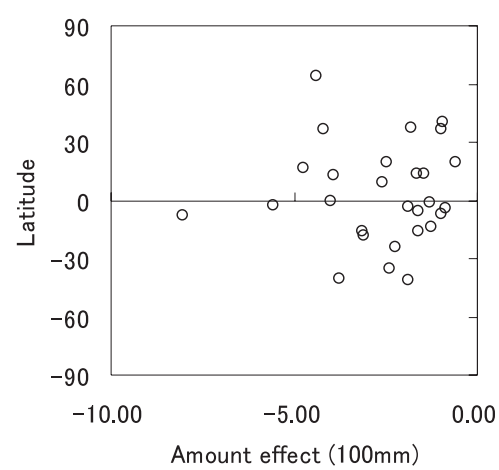

Figure 8 Latitudinal profile of the amount effect of ${ }^{18} \mathrm{O}$ in precipitation.

and middle latitudes (less than $40^{\circ}$ in the Northern and Southern Hemispheres) and had amount effects ranging from $-1.0 \%$ o to $-6.0 \%$ o $/ 100 \mathrm{~mm}$.

\section{Altitude Effect}

Numerous observational studies have examined the relationships between precipitation isotopes and altitude. A decrease in $\delta^{18} \mathrm{O}$ with altitude was observed in Switzerland $(0.26 \% \circ / 100 \mathrm{~m})$ and various regions of Europe $\left(0.16 \%{ }_{0}-0.40 \% / 100 \mathrm{~m}\right.$; Siegenthaler and Oeschger 1982). Similar decreases were also reported in Italy $(0.18 \% \circ / 100 \mathrm{~m}$; Liotta $e t$ al. 2006)) and Slovenia and Croatia (0.24\%/ $100 \mathrm{~m}$; Vreča et al. 2006). Based on the isotopic compositions of yearly and monthly precipitation samples collected in Cameroon and Bolivia, Gonfiantini et al. (2001) reported that the $\delta^{18} \mathrm{O}$ gradient was larger during the rainy period $\left(0.23 \%{ }_{0}-0.26 \%\right.$ o $/ 100 \mathrm{~m}$ in a rainy year versus $0.11 \% 0-0.16 \% / 100 \mathrm{~m}$ in a dry year). Poage and Chamberlain (2001) revealed a consistent and linear relationship between change in the isotopic composition of precipitation and change in elevation (about 0.28\%o/100 m) throughout most mountainous regions of the world except in the Himalayas, at high altitudes, and at extreme latitudes.

Rowley et al. (2001) modeled changes in $\delta^{18} \mathrm{O}$ 
of precipitation at alpine stations of the GNIP/IAEA network using equilibrium fractionation during Rayleigh distillation; comparisons between modeled and observed modern precipitation and elevation revealed close fits. They applied this simple Rayleigh model to estimate the elevation of paleowater in the Himalayas and southern Tibet. The elevation gradients of $\delta^{18} \mathrm{O}$ in this region simulated by the Rayleigh model and GCM simulations were compared to observed data (Hou et al., 2003). The $\delta^{18} \mathrm{O}$ gradients (less than $0.3 \% / 100 \mathrm{~m}$ ) were better simulated by GCMs, which simulate both convection and different moisture origins; in contrast, the Rayleigh models did not reproduce these gradients well, especially for altitudes above 4,000 m.

A surprising result, found by Bowen and Wilkinson (2002), was that the global distribution of $\delta^{18} \mathrm{O}$ in meteoric precipitation was reproduced well with only two geographic parameters (latitude and altitude) by the equation $\delta^{18} \mathrm{O}_{\mathrm{ppt}}=-0.0051\left(|\mathrm{LAT}|^{2}\right)$ $+0.1805(|\mathrm{LAT}|)-0.002(|\mathrm{ALT}|)-5.247$. The average difference between $\delta^{18} \mathrm{O}_{\mathrm{ppt}}$ and the observations, which had a linear relationship with a slope of 1.04 and $R^{2}=0.76$, was $-0.21 \%$. Bowen and Revevaugh (2003) also presented global maps of the interpolated $\delta \mathrm{D}, \delta^{18} \mathrm{O}$, and deuterium-excess in precipitation with $95 \%$ confidence intervals, which can provide input functions for stable isotope hydrological models, serve as a benchmark against which the outputs from isotope-tracerequipped GCMs can be compared, and be used as a template for interpreting $\delta \mathrm{D}$ and $\delta^{18} \mathrm{O}$ archive records.

\section{Models}

\section{Rayleigh-Type Models}

Theoretical approaches to explain isotope variations in meteoric waters evolved from "isolated air mass" models, which are based on Rayleigh condensation, with immediate removal of precipitation and with part of the condensate kept in the cloud during the rain-out process (Hoefs, 2004). Rayleigh-type distillation models successfully reproduce the main characteristics of the global water cycle, particularly the observed strong relationship between local temperature and stable isotopes in precipitation. These models work particularly well at middle and high latitudes where precipitation generation is not dominated by large convective systems (Jouzel et al., 2000). Rozanski et al. (1982) simulated the seasonal and spatial variations in stable isotope ratios in presentday European precipitation with a simple Rayleigh model, reproducing both the continental and seasonal temperature effects fairly well. They noted that the isotopic composition of the local precipitation was primarily controlled by regionalscale processes (i.e., patterns of water vapor transport moving into the continent) and by the average precipitation-evapotranspiration history of the air masses. Local parameters, such as the surface and/or cloud base temperature or the precipitation amount, modified the isotope ratios only slightly.

Yoshimura et al. (2003) developed a Rayleightype isotope circulation model (ICM) that included the Rayleigh equation and external meteorological forcing, and the simulated isotopic fields were compared to the observed values to confirm the reliability of reanalysis datasets (Yoshimura et al. 2004b). Model results from the European Centre for Medium-Range Weather Forecasts (ECMWF) reanalysis datasets better matched the observations (GNIP database), particularly in Europe, than did results based on the National Centers for Environmental Prediction/National Center for Atmospheric Research (NECP/NCAR) reanalysis dataset. This suggests that if modeled atmospheric 
moisture transport is very close to reality, then the predicted variation in precipitation isotopes will be similar to the observed values. In other words, precipitation isotopes can be used to validate the reliability of large-scale water balance and GCM outputs.

\section{GCMs}

The linear relationship between the observed isotopic composition of precipitation and surface air temperature is widely used as a thermometer to reproduce paleoclimate. However, the present linear relationships $\left(\delta^{18} \mathrm{O}\right.$-temperature, $\delta{ }^{18} \mathrm{O}$-precipitation) may be different from those under paleo-isotopic conditions. Temporal biases in the seasonal deposition of precipitation, the condition of the source region, and mixing of ambient air parcels are crucial for quantitatively describing the icecore record (Noone and Simmonds, 2002a). It is important to interpret isotopic variability by comparing paleo- and present-day conditions based on GCM simulations. Table 1 summarizes GCMs and temperature and amount effects simulated by these GCMs under the present-day condition.
Most GCMs can reproduce the temperature and amount effects well in their climatology.

The atmospheric cycles of $\mathrm{HDO}$ and $\mathrm{H}_{2}{ }^{18} \mathrm{O}$ were first simulated using the atmospheric GCM of the Laboratoire de Météorologie Dynamique (LMD) to compare isotopic distributions in precipitation under modern and paleo-conditions; the $\delta{ }^{18} \mathrm{O}$-temperature, $\delta^{18} \mathrm{O}$-precipitation, and $\delta \mathrm{D}-$ $\delta{ }^{18} \mathrm{O}$ relations were realistically simulated under present-day conditions (Joussaume et al., 1984). However, the predicted $\delta^{18} \mathrm{O}$-precipitation slope $(-0.08 \% / 100 \mathrm{~mm} / \mathrm{year})$ was twice that of the observed one $(-0.04 \%)$. Cole et al. $(1993,1999)$ also examined the global relationship between interannual variability in climate and precipitation $\delta^{18} \mathrm{O}$ using the National Aeronautics and Space Administration (NASA) Goddard Institute for Space Studies (GISS) II model with regional vapor source tracers in the hydrological cycle. The model simulated realistic patterns of temperatureisotope correlation but may have overestimated the isotopic influence of the precipitation amount. Simulated changes in vapor source regions reached $10 \%-15 \%$ of the total precipitation. This

Table 1 Description of the GCMs and comparisons of the temperature and amount effects predicted by the models and calculated from GNIP observations.

\begin{tabular}{llllll}
\hline \multicolumn{1}{c}{ Model } & \multicolumn{1}{c}{$\begin{array}{c}\text { Resolution } \\
\text { (lat } \times \text { lon) }\end{array}$} & \multicolumn{1}{c}{$\mathrm{T}\left(<15^{\circ} \mathrm{C}\right)$} & $\mathrm{P}(/ 100 \mathrm{~mm})$ & Origin* & \multicolumn{1}{c}{ References } \\
\hline LMD AGCM & $32 \times 24$ points & $0.55 \sim 0.60$ & $-0.50 \sim-0.79$ & No & Joussaume et al. $(1984)$ \\
& $64 \times 50$ points & $0.57 \sim 0.64$ & -0.62 & Yes & Joussaume \& Jouzel $(1993 \mathrm{a}, \mathrm{b})$ \\
NASA GISS II & $8^{\circ} \times 10^{\circ}$ & 0.59 & $-0.08(/ \mathrm{yr})$ & No & Jouzel et al. $(1987,2000)$ \\
& $8^{\circ} \times 10^{\circ}$ & & -1.2 & Yes & Cole et al. $(1993,1999)$ \\
Hamburg ECHAM4 & $\mathrm{T} 42\left(2.8^{\circ} \times 2.8^{\circ}\right)$ & 0.60 & -1.1 & No & Hoffmann et al. $(1998)$ \\
& $\mathrm{T} 106\left(1.1^{\circ} \times 1.1^{\circ}\right)$ & 0.59 & -0.80 & No & Jouzel et al. $(2000)$ \\
& $\mathrm{T} 30\left(3.75^{\circ} \times 3.75^{\circ}\right)$ & 1.46 (Andes) & -0.80 (Andes) & Yes & Vuille et al. $(2003 \mathrm{a}, \mathrm{b})$ \\
CCSR/NIES AGCM & $\mathrm{T} 21\left(5.6^{\circ} \times 5.6^{\circ}\right)$ & & & Yes & Numaguti $(1999)$ \\
Melbourne Univ. GCM & $\mathrm{R} 21\left(3.25^{\circ} \times 5.625^{\circ}\right)$ & 0.79 & & No & Noone \& Simmonds $(2002 \mathrm{~b})$ \\
GENESIS 2.0 GCM & $\mathrm{T} 31\left(3.75^{\circ} \times 3.75^{\circ}\right)$ & 0.67 & $-0.114(/ \mathrm{yr})$ & No & Mathieu et al. $(2002)$ \\
REMOiso RCM & $0.5^{\circ} \times 0.5^{\circ}$ & 0.56 (Europe) & & No & Strum et al. $(2005)$ \\
\hline GNIP (Observation) & station data & $0.52 \sim 0.69$ & $-0.93 \sim-1.3$ & & all of the above studies \\
& & 0.53 & -1.05 & & this study \\
\hline
\end{tabular}

* Whether the GMS considers the water origin (yes) or not (no) 
suggests that shifts among vapor sources may control the interannual isotopic variability observed in modern precipitation and paleoclimatic records. The ECHAM GCM was developed in collaboration with the ECMWF and the Max Planck Institute for Meteorology in Hamburg, Germany (Hoffmann et al., 1998). The model ran simulations under present-day and last glacial maximum (LGM) conditions (Joussaume and Jouzel, 1993a, b), and the results matched well with the observed and paleoclimatic data of water isotope contents. However, while the simulated $\delta^{18} \mathrm{O}$-temperature relationships for the LGM climate were largely unchanged, the $\delta \mathrm{D}-\delta^{18} \mathrm{O}$ relationships and deuteriumexcess were not sufficient.

The NASA GISS AGCM also simulated the seasonal water isotope cycles under present-day conditions (Jouzel et al., 1987, 1991) and for two spatial resolutions (T42, T21); the high-resolution model produced a more realistic global isotopic water cycle. These three models accurately simulated the linear relation between isotopes and surface temperature at high latitudes (temperature effect) and between isotopes and precipitation (amount effect) in the tropics; similarly, the slopes of $\delta^{18} \mathrm{O}$ temperature and $\delta^{18} \mathrm{O}$-precipitation corresponded well with the observations (Table 1). Using ECHAM-4 and GISS II models, Vuille et al. (2003a) analyzed the interannual variability of ${ }^{18} \mathrm{O}$ in precipitation over the tropical areas of the Americas. Simulations from 1950 and 1980 revealed how variations in temperature, precipitation amount, and moisture-source contributions affected the predicted $\delta^{18} \mathrm{O}$ distribution. However, the simulated $\delta^{18} \mathrm{O}$ in precipitation over the tropical Andes was too enriched because the precipitation amount was underestimated over the Amazon basin. This deficit in simulated rain-out along the trajectory of an air mass moving inland resulted in enriched $\delta^{18} \mathrm{O}$ values. Over parts of the tropical
Americas, the $\delta^{18} \mathrm{O}$ signal was significantly correlated with El Niño-Southern Oscillation (ENSO), reflecting ENSO's role as an integrator of many factors affecting the $\delta^{18} \mathrm{O}$ composition of precipitation. Rather than a GCM, Strum et al. (2005) developed a regional model (REMOiso) fitted with water isotope diagnostics and $0.5^{\circ}$ horizontal resolution; using this model, they simulated the $\delta^{18} \mathrm{O}$ in precipitation over Europe from March 1997 to February 1999. Typical isotopic effects, such as temperature, continental, and altitude effects were successfully reproduced on both annual and seasonal scales.

The Global Environmental and Ecological Simulation of Interactive Systems (GENESIS) model developed at the National Center for Atmospheric Research (NCAR) has been widely used in paleoclimatic studies (Mathieu et al., 2002). The model reproduces the main features of the present-day isotopic field and the characteristic large-scale isotope-climate relationship, but it underestimates the global mean deuterium-excess in precipitation. The origin of the global bias in deuterium-excess clearly lies in the evaporative flux from the ocean. Errors in simulated isotopic fields are caused by local climatic biases in GCMs or by inaccurate parameterizations of isotopic physics. The Center for Climate System Research/National Institute for Environmental Studies (CCSR/NIES) AGCM was developed to simulate the origin and transport of water in the atmosphere-land system over the Eurasian continent (Numaguti, 1999). Most of the liquid precipitation in winter was supplied by ocean water evaporation, but in summer it was mostly supplied by evaporation from the land surface. This result indicates the importance of recycling processes in atmosphereland interactions. Noone and Simmonds (2002b) used the Melbourne University spectral AGCM to simulate the $\delta^{18} \mathrm{O}$ of precipitation and compared 
the results to monthly observations from a global network and daily measurements in southern Australia. Examination of the associations among the modeled isotopic signal, temperature, and precipitation from 1979 to 1995 showed that less than $20 \%$ of the $\delta^{18} \mathrm{O}$ variance could be explained by temperature changes. The association with temperature was strongest when daily data were considered, while precipitation was more important on the interannual timescale. This result suggests that information about individual events is lost through the averaging process.

\section{Land Surface Models}

Isotope tracers are widely used to study hydrological processes in small catchments (e.g., Gibson et al., 2005), but their use in continentalscale hydrological modeling has been limited (Fekete et al., 2006). Isotopes of water have also been used to diagnose the performance of climate and earth system models. Their value as tracers and validation tools in hydrological subsystems derives from the systematic and different paths and residence times they exhibit as a result of phase change, chemical exchange, and diffusive differentiation (Henderson-Sellers et al., 2004). The processes of isotope fractionation, selection, and mixing within the atmosphere-biosphere-lithosphere system can be examined and their isotopic signatures identified. The impact of up-scaling both in the temporal and geographic sense on the isotopic composition of water-cycle components can also be discussed for different climate settings (Gat and Airey, 2006). Fekete et al. (2006) developed an isotope-enabled global water balance/transport model (iWBM/WTM) and conducted simulations and comparisons of isotopic signals in precipitation and river discharge from available datasets, particularly the river isotope dataset from the U.S. Geological Survey (USGS) collected during the 1980s across the contiguous United States (Kendall and Coplen, 2001). The model demonstrated that the primary control of the isotope composition of river discharge is the isotope composition of precipitation, with land surface characteristics and precipitation amount having less impact.

Henderson-Sellers et al. (2002) examined recent changes in stable isotopes of precipitation observed over the Amazon basin, an area influenced by tropical deforestation. Results of GCM simulations of Amazonian deforestation suggested that the recent stable isotope record was more consistent with the combination of predicted greenhouse warming and forest removal than with the predicted effects of deforestation alone. The Isotopes in the Project for Intercomparison of Land Surface Parameterisation Schemes (iPILPS) Phase I experiment was conducted at three sites in South America, Europe, and Australia (HendersonSellers et al., 2006). To provide meteorological and isotopic forcing for the three sites in the iPILPS Phase I experiment, Fischer and Strum (2006) used the regional model REMOiso. Simulated monthly and diurnal variability of $\delta^{18} \mathrm{O}$ in precipitation were compared with GNIP dataset values in three domains. While quantitatively the REMOiso model accurately simulated the seasonality of both precipitation and $\delta^{18} \mathrm{O}$ on a monthly scale, the average diurnal patterns showed both spatial and seasonal differences. Another model that includes stable isotopes in precipitation is the Minimal Advanced Treatments of Surface Interaction and Runoff (Iso-MATSIRO) model developed by Yoshimura et al. (2006), which was used to simulate reasonable features of annual isotopic budgets for the iPILPS experiment sites. Simulated global precipitation ${ }^{18} \mathrm{O}$ by Iso-MATSIRO coupled with an AGCM was closer to the observations than the results obtained by AGCM only; the results also indicated that evaporative isotopic flux 
from the land surface had a large impact on precipitation isotopes over the middle to high latitudinal continental areas.

\section{Applications}

\section{Climate Variability}

Hoffmann and Heimann (1997) noted that it is difficult to use the isotopic composition of paleoprecipitation as a measure of temperature because circulation changes and changing moisture sources play important roles in interpreting a given isotope signal. Shifts among vapor sources may control the interannual isotopic variability observed in modern precipitation and paleoclimatic records (Cole et al., 1999). To interpret isotopic variability as a function of changing atmospheric circulation, such as by ENSO, the Indian Ocean Dipole (IOD), and monsoons, it is important to investigate which factors control the changes in precipitation isotope values in the modern and paleoclimate.

Ichiyanagi et al. (2002) found a close relationship between stable isotopes in Antarctic precipitation and ENSO. A low (high) anomaly of $\delta^{18} \mathrm{O}$ was associated with southerly (northerly) and cold (warm) anomalies, which were considered to be a response to ENSO teleconnection. Noone and Simmonds (2002a) also noted that stable isotopes in Antarctic precipitation were associated with transport processes and the relative contributions of moisture sources. To simulate the ${ }^{18} \mathrm{O}$ signal in three tropical Andean ice cores, Vuille et al. (2003b) used two AGCMs that incorporated stable isotopic tracers and forcing by observed sea surface temperature (SST) for the period 1979 to 1998. More enriched (depleted) $\delta^{18} \mathrm{O}$ in precipitation was associated with warm (cold) conditions in the tropical Pacific. Local climate conditions, temperature, and precipitation amount had significant influences on the $\delta^{18} \mathrm{O}$ signal, but moisture source variability was apparently less significant on the interannual timescale. This result suggests that climate and atmospheric circulation in the tropical Andes are closely correlated with SST anomalies in the tropical Pacific on interannual to interdecadal timescales.

However, in the Asian monsoon regions, more complex factors control the isotopic compositions of precipitation. For example, Araguás-Araguás $e t$ al. (2004) found that stable isotopic compositions in precipitation over the Indian subcontinent and Southeast Asia were correlated with the moisture source and transport patterns but not with the amount of precipitation. Ichiyanagi and Yamanaka (2005) reported that the interannual variation in stable isotopes in precipitation at Bangkok was also influenced by ENSO. Composite mean precipitation was much greater in the isotopic low phase than in the high phase for both May and October, and the amount effect was a main factor in determining the isotopes in precipitation at Bangkok. The precipitation amount responded to coupling of ENSO and the Asian monsoon in May and directly responded to ENSO in October. He $e t$ al. (2006) also showed that isotopic variations at Bangkok were significantly correlated with both ENSO and the IOD. They additionally reported that local vapor contributions might play a role in isotopic ratios during the transition periods of the Asian-Australian monsoon, namely in May and October. Vuille et al. (2005) used the ECHAM4 AGCM to examine the influence of Asian monsoons on the $\delta^{18} \mathrm{O}$ composition of precipitation. Their results indicated that the modern $\delta^{18} \mathrm{O}$ record from the Dasuopu ice core in the Himalayas is a good indicator of large-scale monsoon circulation. The model simulated a significant negative relationship between the $\delta^{18} \mathrm{O}$ composition of precipitation and the vertical wind shear index 
(i.e., large-scale monsoon strength), suggesting that distillation during transport, and hence increased rain-out and depletion of heavy isotopes upstream, may lead to a significant monsoon- $\delta{ }^{18} \mathrm{O}$ relationship in areas where local precipitation is not affected by monsoon variability.

\section{Water Origins}

Deuterium-excess is one of the most useful isotopic tools for defining the formation site and trajectories of atmospheric moisture that gives rise to precipitation (Liotta et al., 2006). The factors controlling precipitation isotopes involve fractionation processes associated with the evaporation and condensation history of the water vapor (Burnett et al., 2004). Therefore, precipitation isotopes and deuterium-excess can be used as tracers of atmospheric circulation. Araguás-Araguás et al. (1998) reported that the seasonal variability of precipitation isotopes was mainly controlled by the precipitation amount effect in Indochina and southern China, where precipitation is brought by the Asian summer monsoon. Ichiyanagi et al. (2005) simulated the daily precipitation $\delta^{18} \mathrm{O}$ and origins of water vapor over Indochina in 2001 using an ICM with tagged water (Yoshimura et al., 2004a). They then proposed a new definition of the Asian monsoon withdrawal date that considered the transition of water origins from the Indian Ocean to the Pacific Ocean. Monthly isotopic compositions and deuterium-excess values have also been found to reflect the trajectory of moist air-mass movement and kinetic fractionation during re-evaporation from falling drops (Datta et al., 1991). In almost all years between 1961 and 1979, Sengupta and Sarkar (2006) found depletion of monthly $\delta^{18} \mathrm{O}$ from September to December because the southwest monsoonal effect had withdrawn and easterlies from the Bay of Bengal had set in. Their examination of weekly data for stable isotopes of precipitation in eastern India, collected in 2004 and 2005, also revealed that precipitation at New Delhi could not be explained by a simple continental effect and a Bay of Bengal vapor source alone. About $20 \%$ of the vapor originated from the Arabian Sea and evapotranspiration from summer monsoon rains.

Based on observations from 1961 to 1962 , Dansgaard (1964) noted that stable isotopes of precipitation in Tokyo were dominated by the temperature effect in winter and by the amount effect during the rest of the year. Dry continental winds collect moisture from the Sea of Japan by fast evaporation (high deuterium-excess) in winter, while southwesterly winds produce occasionally heavy rainfall with low deuterium-excess in the summer. From their analysis of the long-term average of stable isotopes of precipitation, AraguásAraguás et al. (1998) reported that there was little seasonality in the stable isotopes of precipitation at Tokyo and Ryori, Japan, and at Pohang, South Korea. In contrast, deuterium-excess showed a well-marked seasonal trend, with high values during winter (15-25\%) and low values during summer (5$10 \%$ ). During the winter months, dry air masses from the northern Asian continent pass the Sea of Japan and the Yellow Sea, picking up moisture under conditions of reduced relative humidity and lower sea surface temperature. Lee et al. (2003) also showed seasonal variability in deuteriumexcess in northeast Asia. They demonstrated that a cold-day continental polar air mass in winter and a hot-humid maritime tropical air mass in summer brought higher deuterium-excess in winter $(>\sim 15 \%$ ) and lower values in summer $(\sim 10 \%)$, respectively.

Similar high deuterium-excess values have also been observed around the Mediterranean Sea and the Great Lakes area of North America. Leguy et al. (1983) reported that precipitation with greater than $22 \%$ deuterium-excess in Israel was 
associated with an air mass coming from northern Europe, following intense interaction with the Mediterranean Sea. Gat et al. (2003) also observed high deuterium-excess in the atmospheric water vapor over the Mediterranean Sea and confirmed the intensive air-sea interaction and evaporation of sea-spray droplets. The isotopic composition of precipitation and river runoff in the vicinity of the North American Great Lakes was also characterized by increased deuterium-excess, suggesting mixing of recycled evaporated moisture from the lake surface (Gat et al., 1994). Daily precipitation isotopes in New York were collected to examine the relationship between precipitation $\delta^{18} \mathrm{O}$ and atmospheric circulation based on back-trajectory analysis (Burnett et al., 2004). The northwesterly flow across the Great Lakes, which involves relatively warm surface water and creates lakeeffect precipitation, generated the lowest $\delta^{18} \mathrm{O}$ and a relatively high deuterium-excess.

\section{Summary}

In this paper, observation- and model-based studies of stable isotopes in precipitation were reviewed. Global and regional observational networks and projects involving stable isotopes in precipitation have revealed the temporal and spatial distributions of stable isotopes in modern precipitation. The relationships among temperature, precipitation, and stable isotopes have been used as proxies to understand atmospheric circulation patterns and to reproduce the paleoclimate. Recent developments in isotopic studies are summarized as follows: (1) The global distribution of $\delta^{18} \mathrm{O}$ in precipitation is basically controlled by geographical (e.g., latitude, altitude) and meteorological (e.g., temperature, precipitation amount, water vapor source) factors; however, it could be accurately reproduced using only the latitude and altitude of an observation station. (2) A Rayleigh-type model and GCMs can be used to reproduce the temporal and spatial distributions of stable isotopes in precipitation to validate the large-scale water balance and to interpret isotopic variability under the paleoclimate. More observation- and modelbased studies are required for further development of isotope hydrometeorology.

Acknowledgment: I thank the Isotope Hydrology Section of the IAEA for the monthly precipitation isotope data of the GNIP/ISOHIS database. This study was supported by the IORGC for project research in FY 2006-07. This work was also supported by a Grant-in-Aid for Young Scientists (B) 18740302 from the Japanese Ministry of Education, Culture, Sports, Science, and Technology.

\section{References}

Araguás-Araguás, L., Froehlich, K., and Rozanski, K. (1998): Stable isotope composition of precipitation over Southeast Asia. J. Geophys. Res., 103 (D22), 28,721-28,742.

Araguás-Araguás, L., Froehlich, K., Kulkarni, K. M., and Gourcy, L. L. (2004): Stable isotope evidence for moisture sources in the Asian summer monsoon under present and past climate regimes. Geophys. Res. Lett., 31, L08203, doi:10.1029/2004GL019911.

Bowen, G. J., and Wilkinson, B. (2002): Spatial distribution of $\delta^{18} \mathrm{O}$ in meteoric precipitation. Geology, 30 (4), 315-318.

Bowen, G. J., and Revenaugh, J. (2003): Interpolating the isotopic composition of modern meteoric precipitation. Wat. Resour. Res., 39 (10), 1299, doi:10.1029/2003WR002086.

Burnett, A. W., Mullins, H. T., and Patterson, W. P. (2004): Relationship between atmospheric circulation and winter precipitation $\delta^{18} \mathrm{O}$ in 
central New York State. Geophys. Res. Lett., 31, L22209, doi:10.1029/2004GL021089.

Craig, H. (1961): Isotopic variations in meteoric waters. Science, 133, 1702-1703.

Cole, J. E., Rind, D., and Fairbanks, R. G. (1993): Isotopic responses to interannual climate variability simulated by an atmospheric general circulation model. Quat. Sci. Rev., 12, 387-406.

Cole, J. E., Rind, D., Webb, R. S., Jouzel, J., and Healy, R. (1999): Climatic controls on international variability of precipitation $\delta^{18} \mathrm{O}$ : Simulated influence of temperature, precipitation amount, and vapor source region. J. Geophys. Res., 104 (D12), 14,223-14,235.

Dansgaard, W. (1964): Stable isotopes in precipitation. Tellus, 16, 436-468.

Datta, P. S., Tyagi, S. K., and Chandrasekharan, H. (1991): Factors controlling stable isotope composition of rainfall in New Delhi, India. $J$. Hydrol., 128, 223-236.

Fekete, B. M., Gibson, J. J., Aggarwal, P., and Vörösmarty, C. J. (2006): Application of isotope tracers in continental scale hydrological modeling. J. Hydrol., 330, 444-456.

Fischer, M. J., and Strum, K. (2006): REMOiso forcing for the iPILPS Phase 1 experiments and the performance of REMOiso in three domains. Glob. Planet. Change, 51, 73-89, doi:10.1016/ j.gloplacha.2005.12/006.

Fricke, H. C., and O'Neil, J. R. (1999): The correlation between $180 / 160$ ratios of meteoric water and surface temperature: its use in investigating terrestrial climate change over geologic time. Earth Planet. Sci. Lett., 170, 181196.

Gat, J. R., Bowser, C. J., and Kendall, C. (1994): The contribution of evaporation from the Great Lakes to the continental atmosphere: Estimate based on stable isotope data. Geophys. Res. Lett., 21, 557-560.
Gat, J. R., Klein, B., Kushnir, Y., Roether, W., Wernli, H., Yam, R., and Shemesh, A. (2003): Isotope composition of air moisture over the Mediterranean Sea: An index of the air-sea interaction pattern. Tellus, 55B, 953-965.

Gat, J. R., and Airey, P. L. (2006): Stable isotopes in precipitation in the atmosphere/biosphere/ lithosphere interfaces: Scaling-up from the local to continental scale, under humid and dry conditions. Glob. Planet. Change, 51, 25-33, doi:10.1016/j.gloplacha.2005.12/004.

Gibson, J. J., Edwards, T. W. D., Birks, S. J., St. Amour, N. A., Buhay, W. M., McEachern, P., Wolfe, B. B., and Peters, D. L. (2005): Progress in isotope tracer hydrology in Canada. Hydrol. Process., 19, 303-327.

Gupta, S. K., and Deshpande, R. D. (2005): The need and potential applications of a network for monitoring of isotopes in waters of India. Current Sci., 88 (1), 107-118.

Gonfiantini, R., Roche, M.-A., Olivry, J.-C., Fontes, J.-C., and Zuppi, G. M. (2001): The altitude effect on the isotopic composition of tropical rains. Chem. Geol., 181, 147-167.

He, Y., Pang, H., Theakstone, W. H., Zhang, Z., Lu, A., and $\mathrm{Gu}, \mathrm{J}$. (2006): Isotopic variations in precipitation at Bangkok and their climatological significance. Hydro. Process., 20, 2873-2884. doi:10.1002/hyp.6139.

Henderson-Sellers, A., McGuffie, K., and Zhang, H. (2002): Stable isotopes as validation tools for global climate model predictions of the impact of Amazonian deforestation. J. Clim., 15, 26642677.

Henderson-Sellers, A., McGuffie, K., Noone, D., and Irannejad, P. (2004): Using stable isotopes in precipitation to evaluate basin-scale simulations of surface water budgets. J. Hydrometeorol. 5 (5), 805-822.

Henderson-Sellers, A., Fischer, M., McGuffie, K., 
Riley, W. J., Schumidt, G., Strum, K., and Yoshimura, K. (2006): Stable water isotope simulation by current land-surface schemes: Results of iPILPS phase I. Glob. Planet. Change, 51, 34-58, doi:10.1016/j.glopacha.2006.01.003.

Hoefs, J. (2004): Stable isotope geochemistry. Springer-Verlag, $244 \mathrm{p}$.

Hoffmann, G., and Heimann, M. (1997): Water isotope modeling in the Asian Monsoon region. Quaternary International, 37, 115-128.

Hoffmann, G., Werner, G., and Heimann, M. (1998): Water isotope module of the ECHAM atmospheric general circulation model: A study on timescales from day to several years. $J$. Geophys. Res., 103, 16,871-16,896.

Hou, S., Masson-Delmotte, V., Dahe, Q., and Jouzel, J. (2003): Modern precipitation stable isotope vs. elevation gradients in the high Himalaya. Comment on "A new approach to stable isotope-based paleoaltimetry: implications for paleoaltimetry and paleohypsometry of the High Himalaya since the Late Miocene" by David B. Rowley et al. [Earth Planet. Sci. Lett. 188 (2001) 253-268]. Earth Planet. Sci. Lett., 209, 395-399.

Ichiyanagi, K., Numaguti, A., and Kato, K. (2002): Interannual variation of stable isotopes in Antarctic precipitation response to El NiñoSouthern Oscillation. Geophys. Res. Lett., 29 (1), doi:10.1029/2000GL012815.

Ichiyanagi, K., Sugimoto, A., Numaguti, A., Kurita, N., Ishii, Y., and Ohata, T. (2003): Seasonal variation in stable isotopes in alas lakes near Yakutsk, Eastern Siberia. Geochem. J., 37, 519530.

Ichiyanagi, K., and Yamanaka, M. D. (2005): Interannual variation of stable isotopes in precipitation at Bangkok in response to El NiñoSouthern Oscillation. Hydrol. Process., 19, 34133423. doi: 10.1002/hyp.5978.
Ichiyanagi, K., Yoshimura, K., and Yamanaka, M. D. (2005): Validation of changing water origins over Indochina during the withdrawal of the Asian monsoon using stable isotopes. SOLA, 1, 113-116.

International Atomic Energy Agency (1969): World survey of isotope concentrations in precipitation. Tech. Rep. Ser., 69, IAEA, Vienna.

International Atomic Energy Agency (1970): World survey of isotope concentrations in precipitation. Tech. Rep. Ser., 117, IAEA, Vienna. International Atomic Energy Agency (1971): World survey of isotope concentrations in precipitation. Tech. Rep. Ser, 129, IAEA, Vienna. International Atomic Energy Agency (1973): World survey of isotope concentrations in precipitation. Tech. Rep. Ser, 147, IAEA, Vienna. International Atomic Energy Agency (1975): World survey of isotope concentrations in precipitation. Tech. Rep. Ser, 165, IAEA, Vienna. International Atomic Energy Agency (1979): World survey of isotope concentrations in precipitation. Tech. Rep. Ser., 192, IAEA, Vienna. International Atomic Energy Agency (1983): World survey of isotope concentrations in precipitation. Tech. Rep. Ser, 226, IAEA, Vienna. International Atomic Energy Agency (1986): World survey of isotope concentrations in precipitation. Tech. Rep. Ser, 264, IAEA, Vienna. International Atomic Energy Agency (1990): World survey of isotope concentrations in precipitation. Tech. Rep. Ser, 311, IAEA, Vienna. International Atomic Energy Agency (2001): GNIP maps and animations, International Atomic Energy Agency. http://isohis.iaea.org, Vienna.

International Atomic Energy Agency/World Meteorological Organization (2004): Global Network of Isotopes in Precipitation: The GNIP Database. http://isohis.iaea.org, Vienna. 
Joussaume, S., Sadourny, R., and Jouzel, J. (1984): A general circulation model of water isotope cycles in the atmosphere. Nature, 311, 24-29.

Joussaume, S., and Jouzel, J. (1993a): Paleoclimatic tracers: An investigation using an atmospheric general circulation model under ice age conditions 1. Desert dust. J. Geophys. Res., 98 (D2), 27672805.

Joussaume, S., and Jouzel, J. (1993b): Paleoclimatic tracers: An investigation using an atmospheric general circulation model under ice age conditions 2. Water isotopes. J. Geophys. Res., 98 (D2), 2807-2830.

Jouzel, J., Russell, G. L., Suozzo, R. J., Koster, R. D., White, J. W. C., and Broecker, W. S. (1987): Simulations of the HDO and $\mathrm{H}_{2}{ }^{18} \mathrm{O}$ atmospheric cycles using the NASA-GISS general circulation model: The seasonal cycle for present day conditions. J. Geophys. Res., 92, 14,739-14,760.

Jouzel, J., Koster, R. D., Suozzo, R. J., Russell, G. L., White, J. W. C., and Broecker, W. S. (1991): Simulations of the $\mathrm{HDO}$ and $\mathrm{H}_{2}{ }^{18} \mathrm{O}$ atmospheric cycles using the NASA-GISS general circulation model: Sensitivity experiments for present-day conditions. J. Geophys. Res., 96, 7495-7507.

Jouzel, J., Hoffmann, G., Koster, R. D., and Masson, V. (2000): Water isotopes in precipitation: Data/model comparison for present-day and past climates. Quat. Sci. Rev., 19, 363-379.

Kendall, C., and Coplen, T. B. (2001): Distribution of oxygen-18 and deuterium in river waters across the United States. Hydrol. Process., 15, 1363-1393.

Kohn, M. J., and Welker, J. M. (2005): On the temperature correlation of $\delta^{18} \mathrm{O}$ in modern precipitation. Earth Planet. Sci. Lett., 231, 87-96.

Koster, R. D., Jouzel, J., Suozzo, R. J., and Russell, G. (1992): Origin of July Antarctic precipitation and its influence on deuterium content: a GCM analysis. Clim. Dyn., 7, 195-203.
Kurita, N., Numaguti, A., Sugimoto, A., Ichiyanagi, K., and Yoshida, N. (2003): Relationship between the variation of isotopic ratios and the source of summer precipitation in eastern Siberia. J. Geophys. Res., 108 (D11), doi:10.1029/2001JD001359.

Kurita, N., Yoshida, N., Inoue, G., and Chayanove, E. A. (2004): Modern isotope climatology of Russia: A first assessment. J. Geophys. Res., 109 (D03102), doi:10.1029/2003JD003403.

Kurita, N., Sugimoto, A., Fujii, Y., Fukazawa, T., Makarov, V. N., Watanabe, O., Ichiyanagi, K., Numaguti, A., and Yoshida, N. (2005): Isotopic composition and origin of snow over Siberia. $J$. Geophys. Res., 110 (D13102), doi:10.1029/ 2004JD005053.

Lachniet, M. S., and Patterson, W. P. (2006): Use of correlation and stepwise regression to evaluate physical controls on the isotope values of Panamanian rain and surface waters. $J$. Hydrol., 324, 115-140.

Lee, K.-S., Grundstein, A. J., Werner, D. B., Choi, M.-S., Woo, N.-C., and Lee, D.-H. (2003): Climatic controls on the stable isotopic composition of precipitation in Northeast Asia. Clim. Res., 23, 137-148.

Leguy, C., Rindsberger, M., Zangwil, A., Issar, A., and Gat, J. R. (1983): The relation between the ${ }^{18} \mathrm{O}$ and deuterium contents of rain water in the Negev desert and air-mass trajectories. Isotope Geoscience, 1, 205-218.

Liebminger, A., Haberhauer, G., Papesch, W., and Heiss, G. (2006): Correlation of the isotopic composition in precipitation with local conditions in alpine regions. J. Geophys. Res., 111 (D5104), doi:10.1029/2005JD006258.

Liotta, M., Favara, R., and Valenza, M. (2006): Isotopic composition of the precipitations in the central Mediterranean: Origin masks and orographic precipitation effects. J. Geophys. Res., 111 (D19302), doi:10.1029/2005JD006818. 
Mathieu, R., Pollard, D., Cole, J. E., White, J. W. C., Webb, R. S., and Thompson, S. L. (2002): Simulation of stable isotope variations by the GENESIS GCM for modern conditions. J. Geophys. Res., 107 (D4), doi:10.1029/2001JD900255.

Njitchoua, R., Sigha-Nkamdjou, L., Dever, L., Marlin, C., Sighomnou, D., and Nia, P. (1999): Variations of the stable isotopic compositions of rainfall events from the Cameroon rain forest, Central Africa. J. Hydrol., 223, 17-26.

Noone, D., and Simmonds, I. (2002a): Annular variations in moisture transport mechanisms and the abundance of $\delta^{18} \mathrm{O}$ in Antarctic snow. $J$. Geophys. Res., 107 (D24), 4742, doi:10.1029/ 2002JD002262.

Noone, D., and Simmonds, I. (2002b): Associations between $\delta^{18} \mathrm{O}$ of water and climate parameters in a simulation of atmospheric circulation for 1979-95. J. Clim., 15, 3150-3169.

Numaguti, A. (1999): Origin and recycling processes of precipitation water over the Eurasian continent: Experiments using an atmospheric general circulation model. J. Geophys. Res., 104 (D2), 1957-1972.

Oeschger, H. (2000): Perspectives on global change science: Isotopes in the Earth system, past and present. Quat. Sci. Rev., 19, 37-44.

Poage, M. A., and Chamberlain, C. P. (2001): Empirical relationships between elevation and the stable isotope composition of precipitation and surface waters: Considerations for studies of paleoelevation change. Amer. J. Sci., 301, 1-15.

Rozanski, K., Sonntag, C., and Münnich, K. O. (1982): Factors controlling stable isotope composition of European precipitation. Tellus, 34, 142-150.

Rozanski, K., Araguás-Araguás, L., and Gonfiantini, R. (1992): Relation between long-term trends of Oxygen-18 isotope composition of precipitation and climate. Science, 258, 981-984.
Rozanski, K., Araguás-Araguás, L., and Gonfiantini, R. (1993): Isotopic patterns in modern global precipitation. In Climate Change in Continental Isotopic Records, Geophys. Monogr. Ser., 78, edited by Swart, P. R., Lohmann, K. C., McKenzie, J., and Savin, S., AGU, Washington D.C., pp. 1-36.

Rowley, D. B., Pierrehumbert, R. T., and Currie, B. S. (2001): A new approach to stable isotope-based paleoaltimetry: Implications for paleoaltimetry and paleohypsometry of the high Himalaya since the Late Miocene. Earth Planet. Sci. Lett., 188, 253-268.

Sengupta, S., and Sarkar, A. (2006): Stable isotope evidence of dual (Arabian Sea and Bay of Bengal) vapour sources in monsoonal precipitation over north India. Earth Planet. Sci. Lett., 250, 511-521.

Siegenthaler, U., and Oeschger, H. (1980): Correlation of ${ }^{18} \mathrm{O}$ in precipitation with temperature and altitude. Nature, 285, 314-317.

Strum, K., Hoffmann, G., Langmann, B., and Stichler, W. (2005): Simulation of $\delta^{18} \mathrm{O}$ in precipitation by the regional circulation model REMOiso. Hydrol. Process., 19, 3425-3444, doi:10.1002/hyp.5979.

Sugimoto, A., Naito, D., Yanagisawa, N., Ichiyanagi, K., Kurita, N., Kubota, J., Kotake, T., Ohata, T., Maximov, T, and Fedorov A. (2003): Characteristics of soil moisture in permafrost observed in East Siberian Taiga with stable isotopes of water. Hydrol. Process., 17, 1073-1092.

Tian, L., Masson-Delmotte, V., Stievenard, M., Yao, T., and Jouzel, J. (2001a): Tibetan Plateau summer monsoon northward extent revealed by measurements of water stable isotopes. $J$. Geophys. Res., 106 (D22), 28,081-28,088.

Tian, L., Yao, T., Numaguchi, A., and Sun, W. (2001b): Stable isotope variations in the monsoon precipitation on the Tibetan Plateau. J. Meteor. 
Soc. Japan, 79 (1B), 959-966.

Tian, L., Yao, T., Schuster, P. F., White, J. W. C., Ichiyanagi, K., Pendall, E., Pu, J., and Yu, W. (2003): Oxygen-18 concentrations in recent precipitation and ice cores on the Tibetan Plateau, J. Geophys. Res., 108 (D9), 4293, doi:10.1029/2002JD002173.

Tian, L., Yao, T., MacClune, K., White, J. W. C., Schilla, A., Vaughn, B., Vachon, R., and Ichiyanagi, K. (2007): Stable isotopic variations in west China: A consideration of moisture sources. J. Geophys. Res., 112 (D10112), 4293, doi:10.1029/2006JD007718.

Tsujimura, M., Numaguti, A., Tian, L., Hashimoto, S., Sugimoto, A., and Nakawo, M. (2001): Behavior of subsurface water revealed by stable isotope and tensiometric observation in the Tibetan Plateau. J. Meteor. Soc. Japan, 79 (1B), 419-434.

Vuille, M., Bradley, R. S., Werner, M., Healy, R., and Keiming, F. (2003a): Modeling $\delta^{18} \mathrm{O}$ in precipitation over the tropical Americas: 1. Interannual variability and climatic controls. $J$. Geophys. Res., 108 (D6), 4174, doi: 10.1029/ 2001JD002038.

Vuille, M., Bradley, R. S., Healy, R., Werner, M., Thompson, L. G., and Keiming, F. (2003b): Modeling $\delta^{18} \mathrm{O}$ in precipitation over the tropical Americas: 2. Simulation of the stable isotope signal in Andean ice cores. J. Geophys. Res., 108 (D6), 4175, doi:10.1029/2001JD002039.

Vuille, M., Werner, M., Bradley, R. S., and Keiming, F. (2005): Stable isotopes in precipitation in the Asian monsoon region. J. Geophys. Res., 110 (D23108), doi:10.1029/2005JD006022.

Vreča, P., Bronič, I. K., Horvatinčič, N., and Barešič,
J. (2006): Isotopic characteristics of precipitation in Slovenia and Croatia: Comparison of continental and maritime stations. J. Hydrol., 330, 457-469.

Yapp, C. J. (1982): A model for the relationships between precipitation $\mathrm{D} / \mathrm{H}$ ratios and precipitation intensity. J. Geophys. Res., 87 (C12), 9614-9620.

Yoshimura, K., Oki, T., Ohte, N., and Kanae, S. (2003): A quantitative analysis of short-term ${ }^{18} \mathrm{O}$ variability with a Rayleigh-type isotope circulation model. J. Geophys. Res., 108 (D20), 4647, doi:10.1029/2003JD003477.

Yoshimura, K., Oki, T., Ohte, N., and Kanae, S. (2004a): Colored moisture analysis estimates of variations in 1998 Asian monsoon water sources. J. Meteor. Soc. Japan, 82, 1315-1329.

Yoshimura, K., Oki, T., and Ichiyanagi, K. (2004b): Evaluation of two-dimensional atmospheric water circulation fields in reanalyses by using precipitation isotopes databases. J. Geophys. Res., 109 (D20), doi:10.1029/2004JD004764.

Yoshimura, K., Miyazaki, S., Kanae, S., and Oki, T. (2006): Iso-MATSIRO, a land surface model that incorporates stable isotopes in precipitation. Glob. Planet. Change, 51, 90-107, doi:10.1016/ j.gloplacha.2005.12.007.

Zhang, X., Yao, T., Liu, J., Tian, L., and Nakawo, M. (2003): Simulations of stable isotopic fractionation in mixed cloud in middle latitudesTaking the precipitation at Ürümqi as an example. Adv. Atm. Sci., 20 (2), 261-268.

(受付 : 2007年 8 月10日)

(受理 : 2007年10月 4 日)

この論文に対する「討論」を2008年 5 月31日ま で受け付けます。 